\title{
A first record of biphallia in imposexed female of Leucozonia nassa (Caenogastropoda: Fasciolariidae)
}

\author{
Carlos A.O. Meirelles*ł, Ítalo B. Castro ${ }^{\dagger}$ and Jully C.L. Pinheiro*
}

*Universidade Federal do Ceará, Departamento de Biologia, Laboratório de Invertebrados Marinhos (LIMCE), Campus do Pici, CEP. 60455970, Fortaleza, Ceará Brazil. †Fundação Universidade Federal do Rio Grande, C.P. 474, CEP 9620I-900, Rio Grande, RS, Brazil.

‡Corresponding author, e-mail: cameirelles@gmail.com

\begin{abstract}
Imposex is characterized by the development of male characteristics, such as the penis and vas deferens, in female prosobranch gastropods, caused by organotin compounds contamination. In Brazil, imposex was observed in the muricids Stramonita haemastoma and Stramonita rustica and in the olivid Olivancillaria vesica. During the low tide, 54 adult individuals of Leucozonia nassa were manually collected in February 2004 at llha do Japonês tidal flat, Cabo Frio County, Rio de Janeiro State, south-east Brazil. About $98.15 \%$ of females presented imposex $(\mathrm{N}=30)$. Their penises were smaller than male ones. Only I imposexed female presented a biphallia problem, showing 2 flattened penises with a small scourge in the edge. This is the first record of biphallia in an imposexed female of fasciolarid Leucozonia nassa.
\end{abstract}

Imposex is characterized by the development of male characteristics, such as the penis and vas deferens, in female prosobranch gastropods (Smith, 197I). This abnormality is caused by the exposure of those animals to organotin compounds (OTs) in antifouling paints (Gibbs \& Bryan, 1987; Matthiessen \& Gibbs, 1998), used world-wide as covering of boats and other metallic structures in order to prevent incrustations and corrosion, which are processes that drastically reduce the income of boats and the durability of these structures.

The study of imposex has been used at several places around the world as a tool to monitor contamination by organotin compounds, since the methods of chemical analysis are extremely onerous (Oehlmann et al., 1996). In Brazil, imposex was observed in the muricids Stramonita haemastoma (Linnaeus, 1767) (Castro et al., 2000; Fernandez et al., 2002; Fernandez et al., 2005; Castro et al., 2007a,b) and Stramonita rustica (Lamarck, 1822) (Camillo et al., 2004; Castro et al., 2004, 2007) and in the olivid Olivancillaria vesica (Gmelin, I79l) (Caetano \& Absalão, 2003).

During the low tide, 54 adult individuals of Leucozonia nassa (Figure IA) were manually collected in February 2004 at llha do Japonês tidal flat, Cabo Frio County, Rio de Janeiro State, south-east Brazil. The animals were kept in plastic boxes containing seawater from the respective sites and were taken to the laboratory. The molluscs were preliminarily narcotized with magnesium chloride solution 3.5\% (Huet et al., 1995). The soft parts were examined using a binocular microscope. Individuals of Leucozonia nassa with oviducts and penis were considered imposexed females.

The male penis has a robust base and a long scourge in the edge (penis length=9.4 $\pm 1.0 \mathrm{~mm}$ ) (Figure IB). Sometimes its thread-like white tip extended far into the palial cavity; sometimes it was completely retracted into the red base of the copulatory organ.

About $98.15 \%$ of females presented imposex $(\mathrm{N}=30)$. Their penises were smaller than male ones (5.96 $\pm 3.15 \mathrm{~mm}$ in length) (Figure IC) and, in some cases, a well developed vas deferens was observed. Only I imposexed female presented a biphallia problem, i.e. it had a double penis. These flattened penises were similar in shape and length $(4.35$ and $4.75 \mathrm{~mm}$, respectively), with a small scourge in the edge (Figure ID\&E). This is the first record of biphallia in an imposexed female of fasciolarid Leucozonia nassa.

The mechanism leading to imposex in female prosobranch is not well understood, but the inhibition of the cytochrome P450-mediated aromatase activity (CYPI9) (responsible for the conversion of androgens to estrogens) by organotin compounds has been suggested as a possible mechanism for imposex, resulting in increased tissue androgen levels (Bettin et al., 1996).

This tissue proliferation, in advanced levels, blocks the females' genital system (Gibbs \& Bryan, 1987; Gibbs et al., 1987). This situation usually causes sterilization and death due to the presence of aborted capsules in the capsule gland (Gibbs \& Bryan, 1986; Gibson \&Wilson, 2003). Reproductive failure was observed in populations of muricid Nucella lapillus (Linnaeus, 1758) which severely declined during the 1980s in southern England (Gibbs \& Bryan, 1986) due to imposex effects and their intracapsular development (no larval exchange from healthy populations) (Spence et al., 1990). This is an important concern from a conservationist point of view, since high levels of imposex could lead some gastropod populations with intracapsular development to extinction (Gibbs \& Bryan, 1986). 

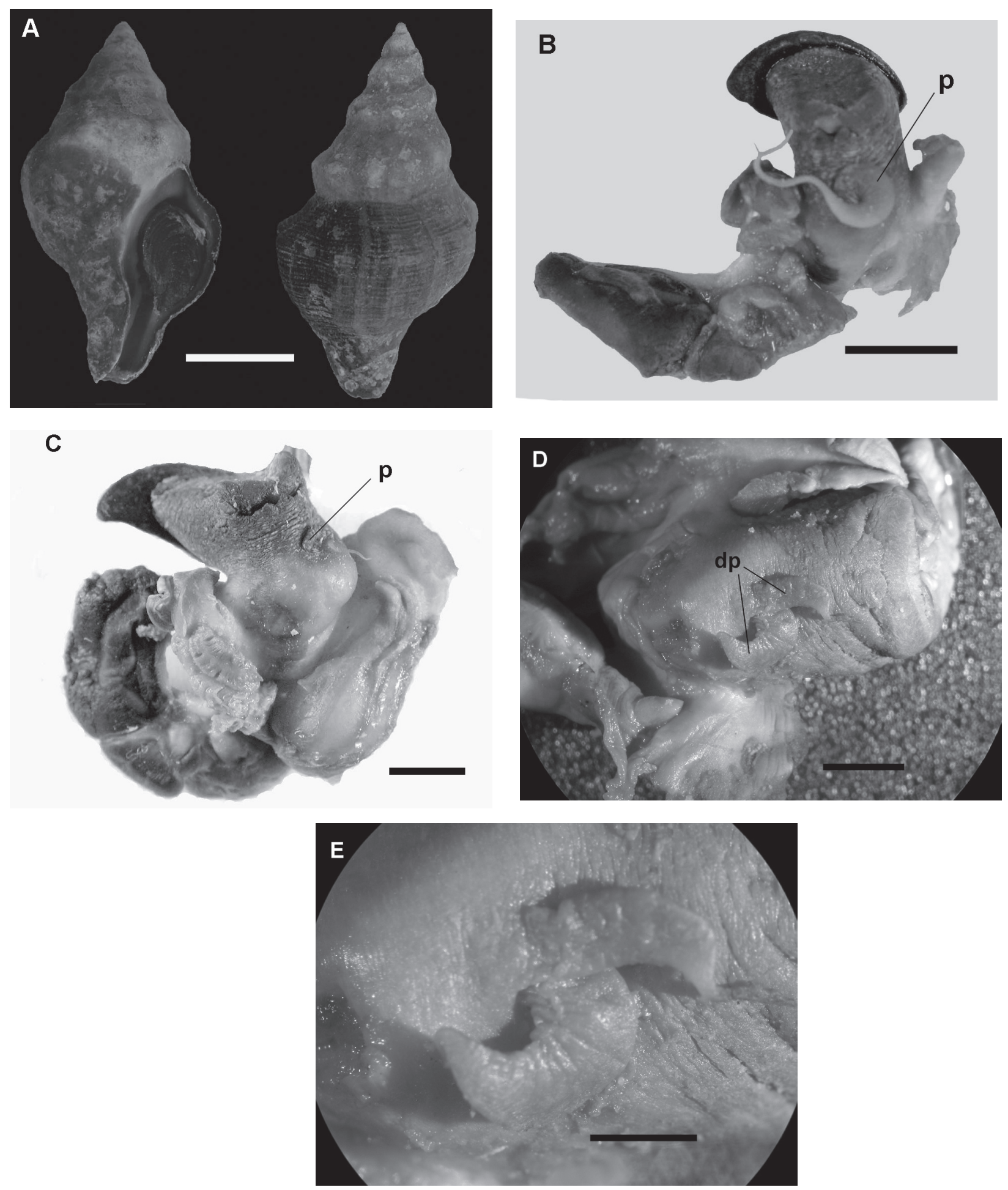

Figure I. Leucozonia nassa. (A) Adult shell; (B) soft parts of an adult male; (C) soft parts of an imposexed female; (D) soft parts of an imposexed female with biphallia; (E) detail of the double penis. Abbreviations: dp, double penis; p, penis. Scale bars: A, $15 \mathrm{~mm}$; B, $5 \mathrm{~mm}$; C, $6 \mathrm{~mm}$; D, $4.5 \mathrm{~mm}$; E, $2.4 \mathrm{~mm}$.

Some countries, such as England and Ireland, have introduced a law that prohibits the use of organotin on vessels under $25 \mathrm{~m}$ and other structures (Evans et al., 199I; Michin et al., 1995). This law has been successful in reducing levels of OTs and imposex levels in dogwhelks over a 6 year period (Michin et al., 1995). Other studies have shown interesting results against imposex effects, such as the co-exposure to 3-MC (3-methylcholanthrene) (McClellan-Green \& Robbins, 2000). It appeared to mediate the endocrine-disrupting effects of OT exposure by reducing the penis size in imposexed females of llyanassa obsoleta (Say, 1822) and restoring their capacity to lay eggs (McClellan-Green \& Robbins, 2000).

The main problem of organotin contamination monitoring is to know the effects of each organotin contamination level on the bioindicators. In another way, the relative organotin sensitivity among species was not tested (Camillo et al., 2004). Since it is probably different between species (Stroben et al., 1995), more studies are required to clarify this question. 


\section{REFERENCES}

Bettin, C., Oehlmann, J. \& Stroben, E., 1996. TBT-induced imposex in marine neogastropods is mediated by an increasing androgen level. Helgoländer Wissenschaftliche Meeresuntersuchungen, 50, 290-317.

Caetano, C.H.S. \& Absalão, R.S., 2003. Imposex in Olivancillaria vesica vesica (Gmelin) (Gastropoda: Olividae) from a Southeastern Brazilian sandy beach. Science of the Total Environment, 976, I-7.

Camillo, E., Quadros, J., Castro, I.B.\& Fernandez, M.A.S., 2004. Imposex in Thais rústica (Mollusca: Neogastropoda) (Lamarck, 1822) as an indicator of organotin compounds pollution at Maceió coast (Northeastern Brazil). Brazilian Journal of Oceanography, 52, I0I-I05.

Castro, I.B., Matthews-Cascon, H. \& Fernandez, M.A., 2000. Imposex em Thais haemastoma (Linnaeus, I767) (Mollusca: Gastropoda), uma indicação da contaminação por organoestânicos na costa no Município de Fortaleza - Ceará - Arquivos de Ciências do Mar, 33, 5I-56.

Castro, I.B., Meirelles, C.A.O., Matthews-Cascon, H. \& Fernandez, M.A.S., 2004. Thais (Stramonita) rústica (Lamarck, 1822) (Mollusca: Gastropoda:Thaididae), a potential bioindicator of contamination by organotin in Northeast Brazil. Brazilian Journal of Oceanography, 52, I35-139.

Castro, I.B., Lima, A.F., Braga, A.R.C. \& Rocha-Barreira, C.A., 2007a. Imposex in two muricid species (Mollusca: Gastropoda) from the northeastern brazilian coast. Journal of the Brazilian Society for Ecotoxicology, 2, 8I-9I.

Castro, I.B., Bemvenuti, C.E., Fillmann, G., 2007b. Preliminary appraisal of imposex in areas under the influence of southern brazilian harbors. Journal of the Brazilian Society for Ecotoxicology, 2, 73-79.

Evans, S.M., Hutton, A., Kendall, M.A. \& Samosir, A.M., 1991. Recovery of dogwhelks, Nucella lapillus (L.) suffering from imposex. Marine Pollution Bulletin, 22, 33I-333.

Fernandez, M.A., Limaverde,A.M., Castro, I.B.,Almeida,A.C.M. \&Wagener,A.L.M., 2002. Occurrence of imposex in Thais haemastoma: possible evidence of environmental contamination derived from organotin compounds in Rio de Janeiro and Fortaleza, Brazil. Brazilian Public Health Report, 18, 463-476.

Fernandez, M.A.S., Wagener, A.L., Limaverde, A.C., Scofield, A.L., Pinheiro, F.M. \& Rodrigues, E., 2005. Imposex and surface sediment speciation: a combined approach to evaluate organotin contamination in Guanabara Bay, Rio de Janeiro, Brazil. Marine Environmental Research, 59, 435-452.

Gibbs, P.E. \& Bryan, G.W., 1986. Reproductive failure in populations of the dog-whelk Nucella lapillus, caused by imposex induced by tributyltin from antifouling paints. Journal of the Marine Biological Association of the United Kingdom, 66, 767-777.

Gibbs, P.E. \& Bryan, G.W., 1987.TBT paints and demise of the dog-whelk Nucella lapillus (Gastropoda). Journal of the Marine Biological Association of the United Kingdom, 68, I 482-I 487.

Gibbs, P. E., Bryan, G.W., Pascoe, P.L. \& Burt, G.R., 1987. The use of dog-whelk Nucella lapillus as an indicator of tributyltin (TBT) contamination. Journal of the Marine Biological Association of the United Kingdom, 67, 507523.

Gibson, C. P. \&Wilson, S.P., 2003. Imposex still evident in eastern Australia 10 years after tributyltin restrictions. Marine Environmental Research, 55, I0I-II2.

Huet, M., Fiorini, P., Oehlmann, J. \& Stroben, E., 1995. Comparison of imposex response in three prosobranch species. Hydrobiologia, 309, 29-35.

Matthiessen, P. \& Gibbs, P.E., 1998. Critical appraisal of the evidence for tributyltin-mediated endocrine disruption in mollusks. Environmental Toxicology and Chemistry, 17, 37-43.

McClellan-Green, P. \& Robbins, J., 2000. Effects of TBT and 3-MC co-exposure on cytochrome P450 expression and activity in marine organisms. Marine Environmental Research, 50, 243-246.

Michin, D., Oehlmann, J., Duggan, C.B., Stroben, E. \& Keating, M.D., 1995. Marine TBT antifouling contamination in Ireland, following legislation in 1987. Marine Pollution Bulletin, 30, 633-639.

Oehlmann, J., Fioroni, P., Stroben, E. \& Markert, B., 1996. Tributyltin (TBT) effects on Ocinebrina aciculata (Gastropoda: Muricidae): imposex development, sterilization, sex change and population decline. Science of the Total Environment, 188, 205-223.

Smith, B.S., 1971. Sexuality in the American mud-snail Nassarius obsoletus Say. Proceedings of the Malacological Society of London, 39, 377-378.

Spence, S. K., Hawkins, S.J. \& Santos, R.S., 1990. The Mollusc Thais haemastoma-an exhibitor of "imposex" and potential biological indicator of tributyltin pollution. Marine Ecology, I I, I47-I56.

Stroben, E., Schulte-Oehlmann, U., Fiorini, P. \& Oehlmann, J., 1995. A comparative method for easy assessment of coastal TBT pollution by the degree of imposex in prosobranch species. Haliotis, 24, I-12.

Submitted 4 May 2006. Accepted 2 July 2007. 